OORRESFOINDEINCE.

ICHTHYOSAURUS ACUTIROSTRIS, ZETLANDICUS, \& LONGIFRONS.

Sir,-On page 313 of the Grologioal Magazine, Dec. IIT. Vol. V. 1888, I stated that I was "disposed to unite both Ichthyosaurus $Z$ etlandicus and $I$. longifrons with $I$. acutirostris. Since that passage was written Prof. Karl von Zittel has been good enough to send me a figure of an entire skull of an Ichthyosaurus from the Upper Lias of Curcy, evidently belonging to $I$. longifrons, which I consider inseparable from I. Zetlandicus. This specimen differs, however, from I. acutirostris in its perfectly straight rostrum; and we have, therefore, $a$ character which (if not merely sexual) will afford a valid distinction between the two forms. If $I$. quadriscissus of Quenstedt be identical with $I$. acutirostris, the name $I$. Zetlandicus, as earlier than $I$. longifrons, should be adopted for the straight-beaked form.

November 17th, 1888.

R. LYDEKKER.

\title{
THE SERPENTINE OF THE LIZARD.
}

SIR,-There are two slight errors in Mr. Somervail's paper "On a Remarkable Dyke in the Serpentine of the Lizard" (p. 553 of last volume), which may mislead readers. They are contained in one sentence, "The dyke forms a portion of the 'granulitic group' of Prof. Bonney, which is now known to be of igneous origin." (1) I have never placed any of the rocks near Pentreath Beach in my "granulitic group," but speak of them more than once as belonging to the "hornblende schists." (2) For "which is now known to be" read "which is now known to include some rocks." The origin of the distinctly "banded gneissic" portion, like that of the banded hornblende schists, cannot be said to be yet known to any one, unless Mr. Somervail has been honoured with a special revelation on the subject. Most persons who have particularly worked at questions of this kind consider the origin of these rocks a very difficult and as yet unsolved problem. The speculations as to the origin and relations of the Lizard rocks, with which Mr. Somervail has favoured us, will no doubt meet with the attention which they deserve, regard being had to the wide experience of their author and his intimate knowledge of rock-structures.

T. G. Bonner.

\section{THE GENUS ASCOCERAS.}

SIR,-The figure which Prof. Lindström gives in the December Number, ${ }^{1}$ of an Ascoceras from the Island of Gothland is a very instructive one-as it supplies some of the earlier septa which have hitherto been wanting and gives a final proof of their existence. It is thus completely confirmatory of the description of the genus which I gave on p. 61 of my British Fossil Cephalopoda. At the time of writing I was obliged to say "the earlier part is unknown" - which still remains partially true-since only three chambers of

1 Geol. MAG. 1888, Dec. III. Vol. V. p. 533, Woodcut. 
the ordinary type are seen in the new specimen; but $I$ had to add " the body chamber and the last few septal chambers only [those which are distorted] being preserved in association." This is now no longer true, but the remainder of my description was entirely based on the probability, not to say the certainty, of such a specimen being ultimately found. It runs, "The earlier septa are of the ordinary kind, with very little convexity and the siphuncle is excentric, in some of large size ... The last few chambers are distorted and their dorsal portions are seldom seen." These dorsal portions, as in the specimen figured by Barrande (Syst. Sil. de la Bohême, vol. ii. p. 513), are well shown in the new specimen. I arrived at the same conclusion as Professor Lindström-that the Ascoceras "is by no means the simplest form of Cephalopod, but the most abnormal," and included it with Poterioceras and others in the group Inflati, the genus being characterized by having its "later septa distorted." The group is said to diverge from the Conici, i.e. the Orthocerata, etc., and to be remarkable for the loss of the early septa.

It is satisfactory that in all these points the new specimens from Gothland confirm the previous observations. J. F. BLAkr.

\section{THE MONIAN SYSTEM,}

Sir,-I feel greatly indebted to Dr. Callaway for introducing the Munian System to the notice of your readers. It was throngh his advice I went to Anglesey, and he naturally takes a fatherly interest in the result.

There are, however, certain points in his "Notes" which call for explanation or reply.

1. I am happy to recognize that Dr. Callaway, in 1887, quite independently of my observations, came to the conclusion that the hornblende-schists were of igneous origin, notwithstanding that such a conclusion entirely overthrew bis reading of the succession in the "gneissic series." I must even confess that he is bolder than I am, for my statement that these schists are igneous, is made in fear and trembling; for though I am forced to it by the stratigraphy, I know it would have been laughed at a few years ago. Nor can I get as far as "foliated felsites," those so considered by Dr. Callaway being compressed and indurated examples of the ordinary mica-schists of the district.

2. As to Parys Mountain, there are two other writers' opinions to consider besides Dr. Callaway's.

3. As to the Llanfechell Grit. I acknowledge it would be of some importance if it could be shown that any large part of the upper portion of the series was made up of fragments of the lower ; but after all the Llanfechell Grits are merely subordinate bands in a long series, and there are no conglomerates in association with them, so that at best any included fragments would be poor evidence. Moreover, it seems quite common in these old rocks, for the earlier deposits to be rapidly altered and to contribute to the later. Thus the con- 